\title{
UNIVERSITY OF NEBRASKA-LINCOLN FUNDAMENTALS OF GEOSCIENCE IN THE FIELD AND METHODS IN GEOSCIENCE FIELD INSTRUCTION
}

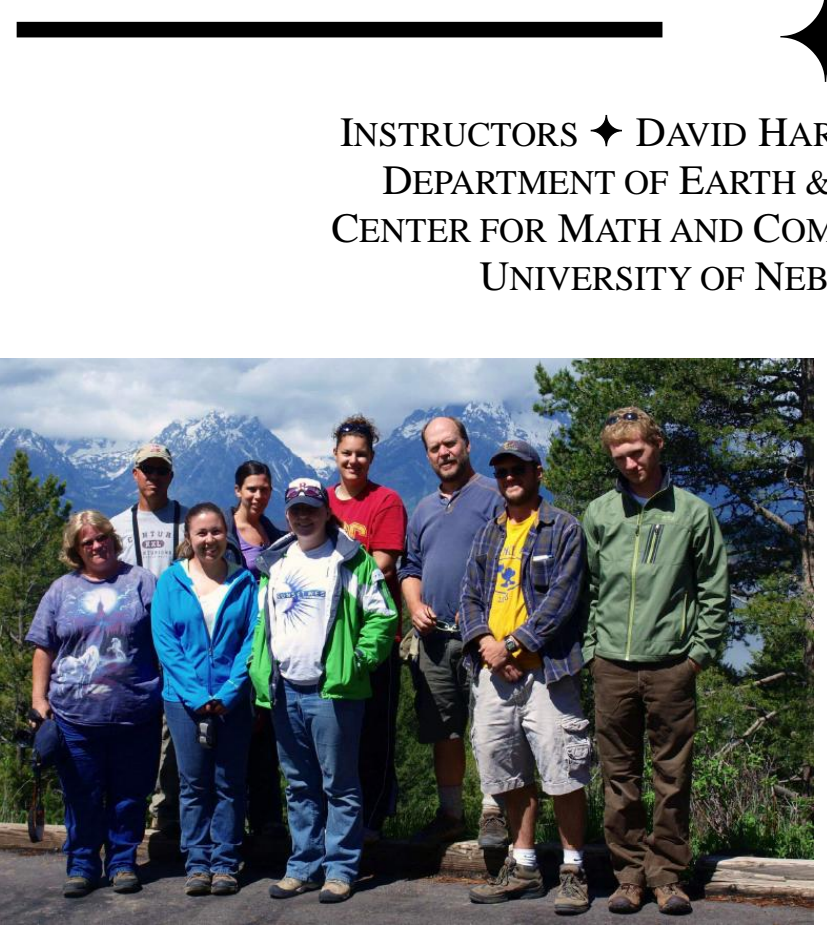

\section{Class OVervieW}

These courses offer teachers an opportunity to learn about the geosciences and geoscience education through a 3-week inquiry-based field course across Wyoming, South Dakota and Nebraska. In 2010, two separate courses utilized the UW-NPS facilities. The group discovered local glacial features, evaluated the uplift and subsidence history of the Grand Tetons and Jackson Hole, respectively, and built upon growing geological abilities and knowledge of the geological evolution of the Rocky Mountain region. The first course (end of May) was directed at pre-service teachers enrolled in the Teacher Education program at the Univ. of Nebraska, and included 6 students and 2 observers from other universities. As part of the Nebraska Math and Science Summer Institute (NMSSI) program, the second course (middle June) was directed at inservice teachers, and included 8 participants. The primary aim of this course is to improve educators' ability to teach inquiry, gain knowledge and understanding of geoscience, and to demonstrate effective teaching methods that can integrate geoscience into K-12 learning environments.

Participants in this course became active members of a field-based learning community comprising individuals with expertise and experience in science and pedagogy. Through a collaborative teaching and learning structure, course participants learned about geoscience, pedagogy, and group dynamics. Although the content of the course was geology, a large portion of the engagement was through the evaluation, assessment and reflection on the inquiry-based approach to teaching geosciences.

\section{$\uparrow \quad$ Class OBJectives}

Major goals of these courses are: (1) to enhance the 'geoscience experience' for pre-service and in-service science educators; (2) to teach inquiry concepts and skills that K-12 educators are expected to understand and teach (as outlined in national standards; (3) to engage science educators in field-based geoscience education and inspire them to use inquiry and geoscience as unifying themes in their classes/teaching activities, (4) to provide participants with an opportunity to pursue authentic geoscience fieldwork, and (5) to enhance pedagogical understanding and provide all participants with a 'tool-kit' of effective inquiry-based, and discoverylearning teaching practices. 